Florida International University FIU Digital Commons

4-27-1981

\title{
The effects and extent of 1,1,1-trichloroethane vapor concentration exposure on workers during solvent vapor degreasing
}

Ahmad Arefian

Florida International University

DOI: $10.25148 /$ etd.FI14030207

Follow this and additional works at: https://digitalcommons.fiu.edu/etd

Part of the Environmental Sciences Commons

\section{Recommended Citation}

Arefian, Ahmad, "The effects and extent of 1,1,1-trichloroethane vapor concentration exposure on workers during solvent vapor degreasing" (1981). FIU Electronic Theses and Dissertations. 1056.

https://digitalcommons.fiu.edu/etd/1056 


\section{ABSTRACT}

THE EFFECTS AND EXTENT OF 1,1,1 - TRICHLOROETHANE VAPOR CONCENTRATION EXPOSURE ON WORKERS DURING SOLVENT VAPOR DEGREASING

\section{by}

\section{Ahmad Arefian}

This study attempted to determine if an excessive amount of $1,1,1$ - Trichloroethane was released into the air, the acute effects of exposure and the cause(s) of excessive use.

The types of degreasing equipments which were tested in this study are straight vapor and the vapor spray machines. The instruments utilized to obtain the data for this study are Gastech Haline Detector, Organic Vapor Monitor Badge and Personal Sampling Pump.

Readings were taken on three different tanks. The data accumulated by this study were obtained during actual cleaning operation. During testing, increased exposure was detected due to exceeding the rate of removal, downward drafts were blowing right over the top of a degreaser and, in some cases, poor general ventilation caused solvent vapor to be blown out of the tank and into the workers' breathing zone, affecting excessive vapor drag out and solvent loss. 
The results show that, since the characteristics of solvent 1,1,1 - Trichloroethane are well suited to vapor degreasing requirements, by using proper procedures and maintenance, 1,1,1 - Trichloroethane emission during vapor degreasing can be controlled at levels well below the industrial hygiene standard established by OSHA for safe and healthful conditions. 
THE EFFECTS AND EXTENT OF $1,1,1$ - TRICHLOROETHANE VAPOR CONCENTRATION EXPOSURE ON WORKERS DURING SOLVENT VAPOR DEGREASING

by

Ahmad Arefian

A thesis submitted in partial fulfillment of the requirements for the degree of MASTER OF SCIENCE

in

ENVIRONMENTAL AND URBAN STUDIES

at

FLORIDA INTERNATIONAL UNIVERSITY

Committee in charge:

Dr. Gabriel Aurioles

Associate Professor and

Committee Chairperson

Dr. Neil Hout-Cooper, Jr.

Assistant Professor

Mr . Ramon P. Cesta

Eastern Air Lines

President, Miami Chapter

AIHA 
To: Dr. Gabriel Aurioles, Dr. Neil Hout-Cooper, Jr., Mr. Ramon P. Cesta

This Thesis, having been approved in respect to form and mechanical execution, is referred to you for judgment upon its substantial merit.

Dean Lambert Tall

School of Technology

The thesis of Ahmad Arefian is approved.
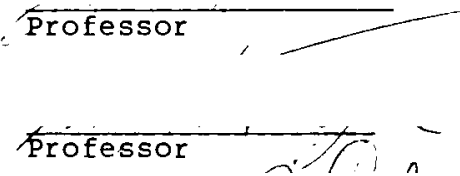

Mr. Ramon P. Cesta

Date of Examination: $A p ;, / \%, 1, \%$ 
THE EFFECTS AND EXTENT OF $1,1,1$ - TRICHLOROETHANE VAPOR CONCENTRATION EXPOSURE ON WORKERS DURING SOLVENT VAPOR DEGREASING

\author{
by \\ Ahmad Arefian
}
A thesis submitted in partial fulfillment of the requirements for the degree of

\author{
MASTER OF SCIENCE
}

in

ENVIRONMENTAL AND URBAN SYSTEMS

at

FLORIDA INTERNATIONAL UNIVERSITY 
I would like to offer my deepest gratitude and appreciation to $\mathrm{Mr}$. Ramon Cesta for giving me the opportunity to conduct my thesis at Eastern Air Lines under the most professional circumstances; for the use of texts, tables, instruments and access to professional laboratory for obtaining sampling results, for time spent in supervising the data collection and review and assisting in all phases of the research. Special thanks to Dr. Aurioles and Dr. Cooper for their guidance and supervision. I would like to acknowledge my wife, Linda, for her marvelous work of proofing and typing. It is hoped that this acknowledgement will in some small way serve as thanks for the support and time spent by all people involved. 
I. LIST OF TABLES

II. INTRODUCTION

A. PREFACE-

B. STATEMENT OF THE PROBLEM-.... 4

C. DEFINITION OF TERMS

III. REVIEW OF THE IITERATURE-

A. INTRODUCTION-

B. $1,1,1$ - TRICHLOROETHANE- $\ldots$

C. HISTORICAL REPORTS-.... 7

D. EXPOSURE AND EFFECTS $\ldots$

1. Central Nervous System-1... 8

2. Skin, Eye and Mucous Membranes-.-......... 9

3. Cardiovascular Effects-_................ 10

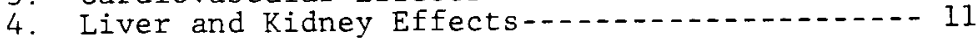

E. SUMMARY - 11

IV. RESEARCH DESIGN AND PROCEDURES

A. BASIS FOR STANDARDS- 13

B. DEGREASIITG EQUIPMENT-.... 14

1. Operation-........ 14



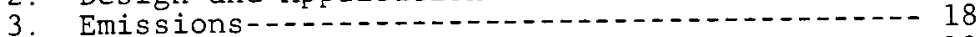

4. Diffusion Losses-........ 19

5. Carry-out Emissions-...... 21

C. MEASURING INSTRUMENTS-........ 24

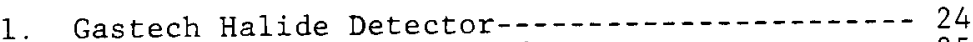



3. Personal Sampling Pump-

V. ANALYSIS-

VI. SUMMARY-1. 36

A. CONCLUSIONS -

B. RECOMMENDATIONS-... 36

VI. LITERATURE CITED $=\cdots$

VII. APPENDIX 
TABLE

1. CONCENTRATION LEVEL OF $1,1,1$ - TRICHLOROETHANE IN THE VICINITY OF TANK \#21-12, MEASURED USING A GASTECH HALIDE DETECTOR ON 11 OCTOBER $1979-$

2. CONCENTRATION LEVEL OF 1,1,1 - TRICHOLORETHANE IN THE VICINITY OF TANK \#C.L. 1, MEASURED USING A GASTECH HALIDE DETECTOR ON 11 OCTOBER $1979---$

3. CONCENTRATION LEVEL OF $1,1,1$ - TRICHLOROETHANE IN THE VICINITY OF TANK \#P-2, MEASURED USING A GASTECH HALIDE DETECTOR ON 25 OCTOBER 1979------

4. CONCENTRATION LEVEL OF $1,1,1$ - TRICHLOROETHANE IN THE VICINITY OF TANK \#21-12, MEASURED USING A PERSONAL SAMPLING BADGE ON 11 NOVEMBER $1979----$

5. CONCENTRATION LEVEL OF $1,1,1$ - TRICHLOROETHANE IN THE VICINITY OF TANK \#21-12, MEASURED USING A PERSONAL SAMPLING PUMP ON 12 NOVEMBER 1979------- 35 


\section{INTRODUCTION}

PREFACE

Metals are of ultimate importance in today's industrial world. Much of our technology depends on metals and their maintenance. cleaning metal parts of their accumulation of grease, oil and dirt is an essential part of the production process in many industries--aircraft, automotive, railroad electronics and household appliances, to cite a few. Parts that have been stamped, machined, welded, soldered and molded are especially susceptible to this dirt build-up; among the many parts are tiny transistors, printed circuit assemblies, precision surgical equipment, diesel motors, airplane components, automotive parts and spacecraft assemblies. Vapor degreasing is one method that can simply, completely and efficiently accomplish this task of cleaning. There are three types of degreasing machines--straight vapor, immersion vapor and vapor spray.

The process of vapor degreasing basically utilizes a solvent in both its liquid and gaseous states. The apparatus produces a controlled cloud of vapor at the solvent's boiling point. Metal objects are immersed in the organic vapor zone and the hot solvent vapor condenses on the object's cooler surface. The flowing liquid solvent then cleans the part by dissolving the residue. The 
grease and liquid solvent drain and are deposited in a tank below. Condensation stops when the metal objects' surface temperature equals the temperature of the vapor solvent. At that time, the part is clean and dry and removed from the vapor zone, ready for reuse or storage. One advantage of vapor degreasing is that pure solvent, instantly made the moment vapor contacts the solid object, does the cleaning and $r$ insing.

Many problems are caused by inefficient, improper and unsafe degreasing practices. These can manifest in health hazards, excessive operating costs, unsatisfactorily degreased work or a combination of the three. The most common problems are excessive solvent consumption, corrosion of the degreaser, stained degreased parts and excessive vapor odors.

The situation of increased vapor concentrations can be very dangerous, not only to the degreaser's operator but others in the vicinity as well. It is imperative to investigate and discover the cause and then proceed to remedy it, as an economy measure as well as a safety precaution. There are many reasons a machine will begin to produce too much vapor. The most common are: excessive rate of immersion or withdrawal of work from unit, improper racking of parts, drafts across open space of unit, spraying above vapor level in solvent flush units, excessive moisture in unit, work baskets too large for unit, overloading unit, too short a cleaning cycle, leaks in solvent compartments of lines, and excessive heat, due to 
either too much heat applied to boiling solvent chamber or failure to turn on cooling water to the condenser.

The purpose of this study was to determine if particular workers were exposed to an excessive amount of 1,1,1 - Trichloroethane vapor concentration and, if so, to find the cause(s) of the problem and to take corrective action, in order to preserve workers' health and reduce operation costs. 


\section{B. STATEMENT OF THE PROBLEM}

The purpose of this study was to determine if an excessive amount of 1,1,1-Trichloroethane vapor concentration was released into the air, exposing particular workers. The most important questions to be answered in this study are as follows:

1. To evaluate the acute effects of the exposure to the operator (s).

2. To determine the cause(s) of any excessive wa ter temperature, contaminated degreaser or excessive heating.

3. To determine the cause(s) of excessive consump tion of degreaser fluid.

DELIMITATIONS OF THE STUDY

This study was conducted at the Eastern Air Lines cleaning and maintenance shop in Miami. This study was limited to the tanks in full operation. Only regular operators and immediate workers vulnerable to the exposure are the subject of this study.

This study attempted to provide the necessary information to take corrective action to protect the workers' health and to minimize the operation cost. 


\section{DEFINITION OF TERMS}

1. TLV - Threshold limit values refer to airborne concentrations under which workers may be repeatedly exposed day after day without adverse effects.

2. TLV-TWA - Threshold limit values - time weighted average concentration for a normal eight hour workday or forty hour work week which workers may be repeatedly exposed, day after day, without adverse effect.

3. TLV-C - Threshold limit value-ceiling. The concentration that should not be exceeded even instantaneously .

4. TLV-STEL - Threshold limit value Short Term Exposure Limit. The maximal concentration to which workers can be exposed for a short period of fifteen minutes continuously. Provided that no more than four excursions per day, with at least sixty minutes between exposure periods and that the TLV-TWA also is not exceeded.

5. ACGIH - American Conference of Governmental Industrial Hygienists, an organization which publishes threshold limit values (TLV) for chemical substances in work room environment.

6. ANSI - American National Standards Institute, Inc., a standards organization which has recommended maximum vapor exposure values for various materials in work room air. 


\section{REVIEW OF THE LITERATURE}

\section{A. INTRODUCTION}

A careful review of books, professional journals, industrial and governmental research related to the topic was conducted. Since the long term effects of exposure were beyond the scope of this study, the main objective was to obtain an overview of the current knowledge concerning the acute effects of excessive exposure to $1,1,1$ Trichloroethane. In addition to this, Trichloroethane's history, current usage and basis for standards was explored.

\section{B. $1,1,1$ - TRICHLOROETHANE}

$1,1,1$ - Trichloroethane was first marketed as an industrial cold cleaning solvent in 1951. In 1961, the production in the United States was 20,000,000 pounds and in 1973 it increased to $438,394,000$ pounds. (OSHA 1976)

There are many uses of 1,1,1 - Trichloroethane as a solvent and cleaning agent. Over forty products, marketed by thirty companies, contain it. NIOSH estimates that $100,000 \mathrm{U.S}$. workers are potentially exposed to 1,1,1 Trichloroethane in their places of employment. (Skory et al. 1974) $1,1,1-\operatorname{Tr}$ ichloroethane is also known as methyl chloroform.

The odor threshold of 1,1,1 - Trichloroethane was reported by the ansi to be around 100 PPM. Other data reports by various researchers state this value from as low 
as 16 and as high as 700 PPM. Variability in odor threshold values highlights the danger of using odor as a criterion for detection of harmful levels of 1,1,1 - Trichloroethane. (ANSI 1970)

\section{HISTORICAL REPORTS}

During the 19th Century, experiments were conducted using 1,1,1 - Trichloroethane. Tauber, in 1880, used Trichloroethane as an anesthetic agent in humans to produce unconsciousness, without excitation or notable effects on respiratory or heart rates. Vomiting and fatigue were experienced during recovery. Tauber experiments with frogs, rabbits and dogs also showed that Trichloroethane did not materially affect respiratory or pulse rates during anesthesia. (Boethner and Muranko 1969)

Experimental studies of Trichloroethane as an inhalation anesthetic with dogs as experimental animals were reported in 1887 by Dubois and Roux. They found that dogs became completely anesthesized in seven to eight minutes when inhaling air saturated with Trichloroethane. There was a slight acceleration of respiration initially, but, with muscular relaxation, the respiration soon became calm and regular. (Row et al. 1963)

\section{EXPOSURE AND EFFECTS}

Based on previous research and experiments, solvent Trichloroethane has been shown to be one of the least toxic of the chlorinated hydrocarbons. In fact, it is 
less toxic than many of the popular aliphatic and aromatic hydrocarbon solvents which have been widely used for many years. (Adefuin and Cornish 1966)

These studies indicate that the most significant findings concerning the effects of Trichloroethane seem to be manifested as depression of the central nervous system (CNS). These include impairment of perceptual speed, reaction time, manual dexterity and equilibrium. (Mccollister et al. 1958) Trichloroethane also affects the cardiovascular system (toxicity). Depression of the circulatory system was found with Trichloroethane, evidenced by a drop in blood pressure. Irritation of the lungs and mucous membranes also has been reported. (Andrews and Stewart 1966)

Both experimental studies and occupational experiences indicate that Trichloroethane is irritating to the skin and mucous membranes and that the nervous system, the cardiovascular system and the liver are affected by exposure.

1. Central Nervous system - The first reported biologic study of Trichloroethane by Tauber in 1880 established that it had anesthetic properties. (Moss and Simmons 1973) Clinical trials from 1958 to 1960 established that it was not very effective as a surgical anesthetic and its use for this purpose was discontinued. The anesthetic properties of Trichloroethane have had occupational significance and will continue to be of significance to work practices and requirements for respiratory protective devices. 
The chief health hazard associated with use of Trichloroethane is through vapor inhalation. The pricipal effect of over-exposure is depression of the CNS, typical of an anesthetic agent. Persons exposed to 900 to 1,000 PPM for twenty minutes or more showed mild indications of readily reversible effects. (ACGIH 1971)

Although other CNS effects which could impair judgment and increase accident $r$ isk have been found with human exposure conditions which would not be anesthetic. Tests have shown impaired perceptual speed, reaction times and manual dexterity during one hour of exposure to $1,1,1$ - Trichloroethane at 350 PPM, but not at 250 PPM. (Frawley 1964) The workers, thus, may become a hazard to himself and to fellow workers.

Similar responses have been found with occupational exposure to $1,1,1$ - Trichloroethane with at least one reported case of sufficient intoxication to cause a fall. (Bass 1970) The use of lids, proper location of tanks and control of solvent temperature will usually keep solvent concentrations in the air at acceptable levels in addition to limiting solvent losses. Special ventilation may be required in some cases.

2. Skin, Eye and Mucous Membranes - Skin irritation has been reported with experimental exposures to $1 \mathrm{i}$ quid Trichloroethane and from occupational use. (Kay 1973) In addition to skin irritation, liquid Trichloroethane can be absorbed to a moderate degree through the 
skin. (Dodd and stewart 1964) Solvent Trichloroethane will remove natural oils from the skin; however, occasional contact should present no problem. Prolonged or frequent contact can defat tissue and cause dermatitis. Such contact should be avoided by the use of proper aprons, gloves, etc.

Eye exposure to liquid Trichloroethane will cause moderate irritation. Such contact usually will not cause serious injury, but discomfort may be appreciable. Care should be taken to avoid splashing in the eyes by wearing goggles or face shields while handling solvent in operations where occurrence is likely.

Trichloroethane is also irritating to the mucous membranes. Lung congestion and edema were found in autopsies of seven workers who were found dead at their site of work with Trichloroethane. (Guy and Otterson 1964)

Transient irritation of the upper respiratory tract and a burning sensation of the tongue were experienced by women exposed to concentrations of Trichloroethane reported to be 10 to $40 \mathrm{PPM}$. However, excretion of TCA by these workers indicated exposures of 500 PPM or more. (Fullerson et al. 1976)

3. Cardiovascular Effects - Sudden death has occurred in humans from both use and misuse of Trichloroethane. At least some of the reported occupational fatalities may have been sudden deaths. (ACGIH 1963) Hypertension was found in six of nine women occupationally exposed to Trichloroethane for several months. Neither 
blood pressure nor ECG changes were found in human subjects experimentally exposed to Trichloroethane at 0 to 2,650 PPM during fifteen minutes or about 1,000 PPM for seventy to seventy five minutes, or 400 to 600 PPM for seven and a half hours. (Erley et al. 1961)

4. Liver and Kidney Effects - Positive urinary urobilinogen was found in two of seven subjects seven hours after an exposure of fifteen minutes to $\mathrm{Tr}$ ichloroethane at 9 to 2,650 PPM. (Stewart 1963) A few red blood cells were found in the urine of five of the subjects. Evidence of kidney injury (red blood cells and protein in the urine) and elevated serum bilirubin were also found in a man following ingestion of Trichloroethane.

Elevated urinary urobilinogen was also found in one subject following a twenty minute exposure at 900 PPM, and some evidence of possible kidney injury was found in six subjects after exposure at 500 PPM for seventy eight minutes. (Stewart 1971) These reports indicate a potential for both kidney and liver injury by Trichloroethane in exposed workers.

\section{E. SUMMARY}

The many uses of $1,1,1$ - Trichloroethane as a solvent cleaning agent in current industrial settings confirmed the need for more research in this area.

Although solvent Trichloroethane has been shown to be one of the least toxic of the chlorinated hydrocarbons, it does warrant careful monitoring as excessive exposure 
will produce various detrimental effects. The review of literature indicates that the most significant findings concerning the effects of Trichloroethane seem to be manifested as depresion of the central nervous system. The cardiovascular system and liver are also affected by exposure. Experimental and occpational experiences indicate that Trichloroethane is irritating to the skin and mucous membranes. This research confirmed the need and approach of this study. 
III. RESEARCH DESIGN AND PROCEDURES

\section{A. BASIS FOR STANDARDS}

The first TLV for Trichloroethane was published by the American Conference of Governmental Industrial Hygienists (ACGIH) in 1953. The value set was a TWA of 500 PPM. The ACGIH published its first documentation for the TLV of 500 PPM for Trichloroethane in 1962. A reduction of the TLV to 350 PPM was recommended by the ACGIH in 1963. The American Industrial Hygiene Association (AIHA) published emergency exposure limits for Trichloroethane in 1964. These limits were 2,500 PPM for five minutes, 2,000 PPM for fifteen and thirty minutes and 1,000 PPM for sixty minutes.

The American National Standard of acceptable concentrations of Trichloroethane published in 1970 gave an acceptable TWA of 400 PPM for protection of health, assuming an eight hour workday, an acceptable ceiling concentration of 500 PPM if the TWA was below 400 PPM, and a maximum peak above the ceiling of 800 for not more than five minutes and not more than once in two hours. The present U.S. Federal standard was adopted from "Threshold Limit Values of airborne concentrations for 1968." It is an eight hour TWA of 350 PPM.

The recommended environmental action limit is based upon CNS responses to acute exposures in man, cardiovascular and respiratory effects associated with 
chronic exposures. With exposures at 500 PPM, seven hours a day for five days, CNS effects such as sleeplessness, lightheadedness and headache were reported. (Stewart 1968)

Trichloroethane has been shown to have a direct effect on the cardiovascular system. At 400 PPM, eye, nose and throat irritation have been experienced by subjects during exposure to $\mathrm{Tr}$ ichloroethane. (Christiansen et al. 1973)

Evidence of CNS response at 450 PPM and minimal to no response at 250 to 350 PPM leads to the conclusion that 350 PPM is a reasonable ceiling concentration. NIOSH recommends that employees be informed of health hazards and that warning signs be posted in appropriate locations in plants where Trichloroethane is manufactured, used or stored.

\section{B. DEGREASING EQUIPMENT}

1. Operation. Vapor degreasers clean through the condensation of hot solvent vapor on colder metal parts. Open top vapor degreasers are batch loaded, i.e., they clean only one work load at a time.

Open top vapor degreasers are estimated to result in the second largest emission of the three categories of degreasers. It is estimated that open top vapor degreasers emit 200,000 metric tons of organics per years, this being about 30 per cent of the national degreasing emissions. 
In the vapor degreaser, solvent vapors condense on the parts to be cleaned until the temperature of the parts approaches the boiling point of the solvent. The condensing solvent both dissolves oils and provides a washing action to clean the parts. The selected solvents boil at much lower temperatures than do the contaminants; thus, the solvent/soil mixture in the degreaser boils to produce an essentially pure solvent vapor.

The simplest cleaning cycle involves lowering the parts into the vapor zone so that the condensation action can begin. When condensation ceases, the parts are slowly withdrawn from the degreaser. Residual liquid solvent on the parts rapidly evaporates as the parts are removed from the vapor zone. The cleaning action is often increased by spraying the parts with solvent (below the vapor level) or by immersing them into the liquid solvent bath.

2. Design and Application

A typical vapor degreaser is a tank designed to produce and contain solvent vapor. At least one section of the tank is equipped with a heating system that uses steam, electricity or fuel combustion to boil the solvent. As the solvent boils, the dense solvent vapors displace the air within the equipment. The upper level of these pure vapors is controlled by condenser coils located on the sidewalls of the degreaser. These coils, which are 
supplied with a coolant such as water, are generally located around the entire inner surface of the degreaser, although for some smaller equipment they are limited to a spiral coil at one end of the degreaser. Most vapor degreasers are also equipped with a water jacket which provides additional cooling and prevents convection of solvent vapors up hot degreaser walls.

The cooling coils must be placed at some distance below the top edge of the degreaser to protect the solvent vapor zone from disturbance caused by air movement around the equipment. This distance from the top of the vapor zone to the top of the degreaser tank is called the freeboard and is generally established by the location of the condenser coils. The freeboard is customarily 50 to 60 per cent of the width of the degreaser for solvents with higher boiling points, such as perchlorethylene, trichlorethylene, and 1,1,1 - Trichloroethane. For solvents with lower boiling poits, such as trichlorotrifluoroethane and methylene chloride, degreasers have normally been designed with a freeboard equal to at least 75 per cent of the degreaser width. Higher freeboards than those recommended will further reduce solvent emissions; however, there comes a point where difficulty associated with moving parts into and out of a degreaser with a high freeboard outweighs the benefit of increased emission control. Nearly all vapor degreasers are equipped with 
a water separator. The condensed solvent and moisture are collected in a trough below the condenser coils and directed to the water separator. The water separator is a simple container which allows the water (being immiscible and less dense than solvents) to separate from the solvent and decant from the system while the solvent flows from the bottom of the chamber back into the vapor degreaser.

The most popular open top vapor degreasers in use range in size from table top models with open top dimensions of 1 foot by 2 feet up to units which are 110 feet long and 6 feet wide. A typical open top vapor degreaser is about 3 feet wide by 6 feet long.

Historically, degreasers of the typical size and smaller have been supplied with a single piece, unhinged, metal cover. The inconvenience of using this cover has resulted in general disuse or, at best, use only during prolonged periods when the degreaser would not be operated, for example, on weekends. More recently, small open top degreasers have been equipped with manually operated roll-type plastic covers, canvas curtains or hinged and counter-balanced metal covers. Larger units have been equipped with segmented metal covers. Finally, most of the larger open top vapor degreasers $(200$ square feet and larger) and some of the smaller degreasers have had manually controlled powered covers.

Lip exhausts are not uncommon, although in use on less than half of the existing open top vapor degreasers. 
These exhaust systems are designed to capture solvent vapors escaping from the degreasers and carry them away from the operating personnel.

Open top vapor degreasers are usually less capital intensive than conveyorized systems, but more capital intensive than cold cleaning equipment. They are generally located near the work which is to be cleaned at convenient sites in the plant, whereas conveyorized vapor degreasers tend to be located at central cleaning stations requiring transport of parts for cleaning. Open top degreasers operate manually and are generally used for only a small portion of the workday or shift.

Open top vapor degreasers are found primarily in metal working plants. Furthermore, the larger the plant, the more likely it will use vapor degreasers instead of cold cleaners. Vapor degreasers are generally not used for ordinary maintenance cleaning of metal parts because cold cleaners can usually do this cleaning at a lower cost. An exception may be maintenance cleaning of electrical parts by means of vapor degreasers because a high degree of cleanliness is needed and there is intricacy of design.

3. Emissions. Unlike cold cleaners, open top vapor degreasers lose a relatively small proportion of their solvent in the waste material and as liquid carry-out. Rather, most of the emissions are those vapors that diffuse out of the degreaser. As with cold cleaning, open 
top vapor degreasing emissions depend heavily on the operator.

An average open top vapor degreaser emits about 2.5 kilograms per hour per $\mathrm{m}^{2}$ of opening 10.5 pounds per hour $\mathrm{ft}^{2}$ ). This estimate is derived from national consumption data on vapor degreasing solvents and from seven EPA emission tests. Assuming an average open top vapor degreaser would have an open top area of about $1.67 \mathrm{~m}^{2}\left(18 \mathrm{ft}^{2}\right)$, a typical emission rate would be 4.2 kilograms per hour or 9,500 kilograms per year $(9$ pounds per hour or 10 tons per year).

4. Diffusion Losses. Diffusion is the escape of solvent vapors from the vapor zone out of the degreaser. Solvent vapors mix with air at the top of the vapor zone. This mixing increases with drafts and with disturbances from cleaned parts being moved into and out of the vapor zone. The solvent vapors thus diffuse into the room air and into the atmosphere. These solvent losses include the convection of warm, solvent-laden air upwards out of the degreaser.

Diffusion losses from the open top vapor degreaser can be minimized by the following actions:
a. closing the cover;
b. minimizing drafts;
c. providing sufficient cooling by the condensing coils; 
d. spraying only below the vapor level;

e. avoiding excessively massive work loads;

f. maintaining an effective water separator;

g. promptly repairing leaks.

The cover must be closed whenever the degreaser is not in use. This includes shutdown hours and times between loads. Cover design is also important. Improved designs for the cover can make it easier to use, thereby facilitating more frequent closure. Covers should also be designed to be closed while a part is being cleaned in the degreaser .

Drafts can be minimized by avoiding the use of ventilation fans near the degreaser opening and by placing baffles on the windwrd side of the degreaser. A baffle is simply a vertical sheet of material placed along the top of the degreaser to shield the degreaser from drafts.

sufficient cooling by the condensing coils should be attained by following design specifications for the degreaser. Cooling rate is a function of solvent type, heat input rate, coolant temperature and coolant flow. If the vapor level does not $r$ ise above the midpoint of the cooling coils, then the cooling rate is probably adequate. (ACGIH 1968)

The solvent must not be sprayed above the vapor level because such spraying will cause solvent vapors to mix with the air and be emitted. When this occurs, the operator should wait for the vapor level to return to normal and then should cautiously operate the spray wand only 
below the vapor level.

A massive work load will displace a large quantity of solvent vapor. The work load should not be so massive that the vapor level drops more than about $10 \mathrm{~cm}$ (4 inches) (ACGIH 1966) as the work load is removed from the vapor zone. Otherwise, excessive quantities of solvent vapors will mix with the air as the vapor level falls and rises.

The water separator should be kept properly functioning so that water does not return to the surface of the boiling solvent sump. Water can combine with the solvent to form an azeotrope, a constant boiling mixture of solvent and water that has a lower vapor density and higher volatility than does pure solvent vapor. (Nelson and Shapiro 1971)

Lastly, it is important for any leaks to be repaired properly and promptly. Special attention should be paid to leaks of hot solvent because hot solvent evaporates quickly. These leaks may be greater than they appear or go completely unnoticed.

5. Carry-Out Emissions. Carry-Out emissions are the liquid and vaporous solvent entrained on the clean parts as they are taken out of the degreaser. Crevices and cupped portions of the cleaned parts may contain trapped liquids or vapors even after the parts appear to be dried. Also, as the hot cleaned part is withdrawn from the vapor zone, it drags up solvent vapors and heats solvent-laden air, causing it to convect upwards out of the degreaser. 
There are seven factors which directly affect the rate of carry-out emissions:

a. porosity or absorbency of work loads;
b. size of work loads in relation to the degreaser's vapor area;

c. racking parts for drainage;

d. hoist or conveyor speed;

e. cleaning time in the vapor zone;

f. solvent trapped in cleaned parts;

g. drying time.

Porous or absorbent materials such as cloth, leather, wood or rope will absorb and trap condensed solvent. Such materials should never enter a vapor zone.

The work load preferably should not occupy more than one-half of the degreaser's working area. (ACGIH 1953) Otherwise, vapors will be pushed out of the vapor zone by means of a pistol effect.

Proper racking of parts is necessary to minimize entrainment (cupping) of solvent. For example, parts should be positioned vertically with cups or crevices facing downward.

A maximum hoist speed of 3.3 meters per minute (11 feet per minute) has been generally accepted as reasonable by the degreasing industry. (Hoyle et al. 1956) Rushing work loads into and out of the degreaser will force solvent vapors out into the air and leave liquid solvent on the cleaned parts which can subsequently evaporate into the air. 
Cleaning time is the period the work load remains in the vapor zone. If this is not long enough to allow the work load to reach the temperature of the condensing vapor, the parts will not dry properly when removed from the vapor zone. The work load should remain in the vapor zone until the vapors no longer condense on the parts. (Kupel et al. 1970) Usually 30 seconds is sufficient; however, massive work loads may require longer periods. (Feiner and Kleinfeld 1966)

Before the cleaned parts emerge from the vapor zone, they should be tipped and/or rotated to pour out any collected liquid solvent. The work load should be removed from the vapor zone slowly (at a vertical speed not to exceed 11 feet per minute).

6. Exhaust Emissions. Exhaust systems are often used on larger than average open top vapor degreasers. These systems are called lip or lateral exhausts and they draw in solvent-laden air around the top perimeter of the degreaser. Although a collector of emissions, an exhaust system can actually increase evaporation from the bath, particularly if the exhaust rate is excessive. Some exhaust systems include carbon adsorbers to collect the exhaust solvent for reuse; thus, exhaust emissions can be nearly eliminated if the adsorbtion system functions properly.

In some poorly designed exhaust systems, the ventilation rate can be too high. If the air/vapor interface 
is disrupted by high ventilation rates, more solvent vapors will mix with air and be carried out by the exhaust system. A rule of thumb used by manufacturers of degreaser equipment and control systems is to set the exhaust rate at 50 cubic feet per minute per square foot of degreaser opening $\left(15 \mathrm{~m}^{3}\right.$ per minute $\mathrm{m}^{2}$ ) (Cropper and $\mathrm{Ka}-$ minski 1963)

The primary objecive of exhausting is to assure that the threshold limit value (TLV) as adopted by OSHA is not exceeded. The exhaust level recommended above is satisfactory for OSHA requirements on ventilation except when the quality of operation of the degreaser is rated as "average" or "poor." Poor operation is noted by OSHA to include excess carry-out of the vapor and liquid solvent, contamination of the solvent or improper heat balance. In these cases, and for solvents with aTLV $\geq 100 \mathrm{ppm}$, the minimum OSHA ventilation requirement is 75 or 100 cubic feet per minute per square foot of degreaser opening. Consequently, atmospheric emissions from poorly operated degreasers are increased even further.

C. MEASURING INSTRUMENTS

Following is a description of the various instruments utilized to obtain the data for this study.

1. Gastech Halide Detector. The Gastech Halide Detector is a lightweight portable instrument for continuous or intermittent measurement of airborne halogenated 
compounds. The principle of operation is based on the increase of spectral intensity of an AC spark, which brightens when a halogenated compound is present. The brightness of the spark in the ultraviolet region is directly proportional to the halogen concentration of the gas sampled. This increase in brightness, filtered through an ultraviolet transmitting filter, is displayed on a panel meter. Halide meters are made to detect the increase in the brightness of an arc. This instrument is sensitive to all halogens and halogenated compounds, and consequently they are not specific for Trichloroethane. Halide meters are suitable for continuous monitoring if Trichloroethane is the only halogenated contaminant present in the sampled air. (Tables 1,2 and 3 )

2. Organic Vapor Monitor Badge. This is a badge assembly to be worn near the breathing zone of personnel exposed to potentially hazardous organic vapor environments. It is designed to measure time-weighted average concentrations over a measured time interval of eight hours or less. The monitor requires no sampling pump. The contaminant enters the monitor by diffusion and is absorbed by an active absorbent medium in the badge interior. The amount of contaminant absorbed is determined by exposure time and contaminant concentrations in the monitored environment. The weight of the contaminant is related to the time-weighted average worker exposure. (Table 4) 
3. Personal sampling Pump. The apparatus used for charcoal tube sampling is a battery-operated pump with a clip that attaches to the worker in a vertical position. The charcoal tube is flame-sealed at both ends which are broken immediately before sampling. (Table 5)

The sampling pump's calibration and volumetric flow rate should be checked before and during each survey to obtain the most accurate results. This small portable sampling device contains no liquid and one basic procedure determines many different organic compounds. Analysis of the tubes can be quickly accomplished.

Due to the weight of Trichloroethane, the tube is susceptible to overloading and the possibility of appreciable sample loss exists. High concentrations of other organic compounds may also displace Trichloroethane from the charcoal. Air samples of the breathing zones of individual workers should be collected in an attempt to characterize their exposure. 


\section{ANALYSIS}

Six readings were taken on three different tanks: two stright type degreasers (Tables 2 and 3 ) were each surveyed once with the Gastech Halide Detector. One spray type (Table 1 ) had four readings; two with the Halide Detector (Table 1), one with the Personal Sampling Pump (Table 5) and one with the personal Sampling Badge (Table 4) . The data accumulated by this study were obtained during actual cleaning operation; while placing parts into the degreaser, cleaning, spraying and during the removal and unloading of the parts. The Halide Detector and Personal Sampling Pump were calibrated prior to each survey. Based on the method of calibration, the accuracy of the Halide Detector is $+10 z$ and the Personal Sampling Pump is +58 .

Prior to and during each survey, the operator (s) and/or supervisors were asked questions relating to the research. The operators were informed that the survey was part of a research study to determine if problems existed so they could be corrected. The work cycle was observed and the sampling monitored solvent vapor concentrations in the breathing zones and also general areas.

Table 1 shows the results of two testings on a spray type degreaser with a Gastech Halide Detector. The tank was located in a large room with twelve other chemical cleaning and carbon removing tanks. Each cleaner had an exhaust system, and outside air was forced in from the 
ceiling. Lip exhaust ventilation was provided at this degreaser and the lip slots were found to be open.

The tank was basically used by one operator. But two or three other employees could have been exposed at any given time. In the first test, the average vapor concentration measured in the breathing zone of the operator was exceedingly high. Coupled with the presence of a strong odor detected during a visual inspection of the tank, the machine was shut down for maintenance and repair. After the mechanical adjustment, the second testing indicated considerable reduction of $1,1,1$-Trichloroethane in the workers' breathing zone.

During both testings, increased exposure occurred while parts were being removed from the degreaser. One reason for this is that the operator frequently exceeded the recommended rate of removal of 11 feet/minute, which in this case was 13 feet/minute. The swift motion in pulling loads from the degreaser dragged solvent vapor from the unit directly into the workers' breathing zone. 
TABLE 1

CONCENTRATION LEVEL OF $1,1,1$ - TRICHOLORETHANE IN THE VICINITY OF TANK \#21-12, MEASURED USING A GASTECH HALIDE DETECTOR ON 11 OCTOBER 1979

Tank Side Range Mean (PPM) $\mathrm{mg} / \mathrm{m}^{3}$

$\begin{array}{ccccc} & \text { North- } & 29-43 & 500 & 2730 \\ \text { Test } 1 \text { South- } & 30-42 & 520 & 2839 \\ & \text { East- } & 22-38 & 400 & 2184\end{array}$

$\begin{array}{rcrrr} & \text { North- } & 22-40 & 410 & 2239 \\ \text { Test } 2 \text { South- } & 0-32 & 150 & 819 \\ & \text { East- } & 16-19 & 140 & 764\end{array}$

Type of tank: Pressure-spray

Tank size: $60 \times 60 \times 50$ inches

Heat source: Steam

Solvent Temperature: $145^{\circ}-160^{\circ} \mathrm{F}$.

Time of sample collection: $11: 30 \mathrm{a} . \mathrm{m}$.

Sample duration: 25 minutes

Rate of removal (unloading parts): 13 feet/minute Weekly solvent consumption: 110-165 gallons 
The vapor loss was limited to some extent by the use of covers and screens at the tank. Although solvent 1,1,1 - Trichloroethane has a high vapor solvent density and little tendency to $r$ ise above the condensing level, air currents or drafts across the degreaser will cause substantial mixing of air with the solvent vapor and result in solvent losses. For this reason, a degreaser should be located away from open doors, windows or fans. 
TABLE 2

CONCENTRATION LEVEL OF $1,1,1$ - TRICHLOROETHANE IN THE VICINITY OF TANK \# C.L. 1, MEASURED USING A GASTECH HALIDE DETECTOR ON 11 OCTOBER 1979

Tank Side Range Mean (PPM) $\mathrm{mg} / \mathrm{m}^{3}$

$\begin{array}{lllll}\text { Test I } & \text { North } & 19-47 & 445 & 2430 \\ \text { fan on } & \text { South } & 33-61 & 780 & 4259 \\ & & & & \\ \text { Test } 2 & \text { North } & 17-70 & 500 & 2730 \\ \text { fan off } & \text { South } & 17-40 & 280 & 1529\end{array}$

Type of tank: straight

Tank size: $84 \times 36 \times 15$ inches

Heat source: Steam

Solvent Temperature: $145^{\circ}-160^{\circ} \mathrm{F}$.

Rate of removal: Manual

Sample duration: 40 minutes

Time of sample collection: 2:00 p.m.

Weekly solvent consumption: 60-100 gallons 
TABLE 3

CONCENTRATION LEVEL OF $1,1,1$ - TRICHLOROETHANE IN THE VICINITY OF TANK \#P-2, MEASURED USING A GASTECH

HALIDE DETECTOR ON 25 OCTOBER 1979

Tank Side

North

South

West
Range

$18-50$

$19-34$

$16-31$
Mean (PPM)

$\mathrm{mg} / \mathrm{m}^{3}$

2129

1638

1420

Type of tank: Straight

Tank size: $48 \times 30 \times 12.5$ inches

Heat source: Steam

Solvent temperature: Not known (no gauge)

Time of sample collection: 2:15 p.m.

Sample duration: 20 minutes

Rate of removal: manual

Weekly solvent consumption: 55-110 gallons 
Personal samplers were used to obtain the data for Tables 4 and 5. The workers wore these testing devices to measure their average exposure over part of the working day $(21 / 2-3$ hours $)$.

The personal sampling badge obtained the measurements in Table 4. However, there are extremely different results in the exposure of employees $A$ and $B$. But the difference is believed to be because of tampering with the badge and interfering with sampling by employee $A$. Therefore, the high exposure concentration to him was considered inaccurate and not representative of the situation. Further sampling of the same work place and working conditions was obtained through the use of a personal sampling pump (Table 5). The charcoal tube samples were sent to the laboratory and analyzed by gas chromotography. The results indicate that the presence of solvent vapor in the working area is far below the TLV for 1,1,1 -Trichloroethane and this was considered to be the representative exposure concentration. 
TABLE 4

CONCENTRATION LEVEL OF $1,1,1$ - TRICHLOROETHANE IN THE VICINITY OF TANK \#21-12, MEASURED

USING A PERSONAL SAMPLING BADGE ON 11 NOVEMBER 1979

Employee

Exposure Time $\mathrm{mg} / \mathrm{m}^{3}$

PPM

A

162 minutes

12470

162 minutes

161

2285

30

Solvent temperature: $140^{\circ} \mathrm{F}$. Time of sample collection: $11: 18 \mathrm{a} . \mathrm{m}$.

Sample duration: 162 minutes 


\section{TABLE 5}

CONCENTRATION LEVEL OF 1,1,1 - TRICHLOROETHANE

IN THE VICINITY OF TANK \#21-12 MEASURED

USING A PERSONAL SAMPLING PUMP

ON 12 NOVEMBER 1979

Exposure Time Flow Rate (of the pump) $\mathrm{mg} / \mathrm{m}^{3}$ TWA (PPM)

180 minutes $\quad 25 \mathrm{cc} /$ minute $\quad 251 \quad 46$

Solvent temperature: $140^{\circ} \mathrm{F}$.

Time of sample collection: 10:06 a.m.

Sample duration: 3 hours

Water temperature: $99^{\circ} \mathrm{F}$. 


\section{SUMMARY}

\section{A. CONCLUSIONS}

Since the characteristics of solvent $1,1,1-\operatorname{Tr} i-$ chloroethane are well suited to vapor degreasing requirements, solvent 1,1,1 - Trichloroethane can be used effectively in most vapor degreasing operations and is applicable to all the common industrial metals. The vapor degreasing process usually yields the desired degree of cleanliness if the sizes, shapes and contaminants are correlated to the proper cleaning cycle.

The rapid evaporation rate of solvent 1,1,1 -Trichloroethane increases cleaning capacity by decreasing drying time. However, this same characteristic requires reasonable care to control the loss of solvent through evaporation.

In summary, the results show that by using proper procedures and maintenance, Trichloroethane emissions during vapor degreasing can be controlled at levels well below the Industrial Hygiene standard established by osHA for safe and healthful conditions.

B. RECOMMENDATIONS

There are no special or specific physical requirements for operating properly functioning degreasers. Any person acceptable for employment in any other area in normal physical condition would be able to operate a degreaser. However, operators must be well instructed in proper working techniques if contamination of the area is 
to be avoided. All the new and present employees in any $1,1,1$ - Trichloroethane area should be kept informed of the hazards, relevant symptoms, effects of over-exposure, proper working conditions and precautions concerning the safe use of 1,1,1 - Trichloroethane. No one should ever be permitted to remain in an area contaminated by a leaking or otherwise malfunctioning degreaser, regardless of his health status.

It is most important that the machine be operated so as to create a minimum disturbance of the vapor level. The following recommendations are necessary to maintain an efficient, safe working environment:

1. Degreasing tanks should be sited in well ventilated areas, giving particular attention to tanks in confined areas, while open tanks should be located away from heaters, drafts and ventilators.

2. Work should be arranged so that it can be contained in the freeboard zone of the tank during the removal of excess solvent and stacked to insure complete drainage of the degreasing solvent.

3. Avoid excessive work loads as it condenses the vapor too fast and lowers the temperature level.

4. To minimize exposure to 1,1,1 -Trichloroethane, parts should be withdrawn slowly from the degreaser so as not to pull solvent out.

5. The nozzle of the spray should be kept below the vapor-air interface during spraying applications. 
6. Vapor degreasing tanks should be provided with efficient lip exhaust systems and covered by protective screens to prevent escape of $1,1,1$-Trichloroethane vapor.

7. Air flow in the degreasing area should be controlled so drafts do not sweep across the top of the vapor degreaser or toward the operator and lip exhaust should be properly operated.

8. When the machine is in operation the distance from the vapor level to the top should be no less than one-half the tank width or 36 inches (91 centimeters), whichever is shorter.

9. A continuing strong or objectionable odor should not be tolerated. It is an indication of excessive solvent vapor in the air. The odor of vapor degreasing solvents cannot be relied on as the only indicator of overexposure. Measurement of solvent concentrations in air must be made to assure safety of workmen and compliance with the regulations.

10. Small spillage and leakage should be cleaned up immediately, placing solvent saturated rags in a closed container or outdoors until thoroughly dry. Major spills will require the use of respiratory protections.

11. Operator should not smoke cigarettes while handing chlorinated solvents. 


\section{LITERATURE CITED}

ACGIH. 1953. American conference of governmental industrial hygienists. 1953. Report of the committee on threshold-limits, pages 45-47, in Transactions of the 15th annual meeting of the ACGIH. Los Angeles.

ACGIH. 1963. American conference of governmental industrial hyugienists. 1963. Report of the committee on threshold limit values, pages 77- 79, in Transactions of the 25th annual meeting of the ACGIH. Cincinnati, Ohio.

ACGIH. 1966. American conference of governmental industrial hygienists. 1966. Methyl chloroform (1,1,1 Trichloroethane), pages 124-25, in Documentation of threshold limit values. Revised ed. Cincinnati, ohio.

ACGIH. 1968. American conference of governmental industrial hygienists. 1968. Threshold limit values of airborne contaminants for 1968--recommended and intended values, pages 5-10, in Transaction of the 30 th annual meeting of ASGIH. St. Louis, Missouri.

ACGIH. 1971. American conference of governmental industrial hygienists. 1971. Methyl chloroform $(1,1,1$ Trichloroethane) in documentation of threshold limit values for substances in workroom air. ed. 3. Cincinnati, Ohio. 161-162 pp.

Adefuin, J. and J. J. Cornish. 1966. Ethanol potentiation of halogenated aliphatic solvent toxicity. Am. Ind. Hyg. Assoc. $J$ 27:57-61.

Andrews, J.T. and R. D. Stewart. 1966. Acute intoxication with methyl chloroform. JAMA 195: 904-06.

ANSI. 1970. American National Standard Institute. 1970. American national standard acceptable concentrations of methyl chloroform (1,1,1 - Trichloroethane). New York, N.Y. 8 pp.

Bass, M. 1970. Sudden sniffing death. JAMA 212: 2075-79.

Boettner,E.A. and H. J. Muranko. 1969. Animal breath data for estimating the exposure of humans to chlorinated hydrocarbons. Am. Ind. Hyg. Assoc. J 30: 437-42.

Christiansen, V.O., J.A. Dahlberg and E. A. Eriksson. 1973. On the formation of methyl chloroform in welding. Ann. Occup. Hyg. 16:41-46. 
Cropper, F.R. and S. Kaminski. 1963. Determination of toxic organic compounds in admixture in atmosphere by gas chromatography. Am. Ind. Hyg. Assoc. J 31: 225-32.

Dodd, H.C. and R. D. Stewart. 1964. Absorption of carbon tetrachloride, trichloroethylene, methylene chloride and $1,1,1$ - Trichloroethane through the human skin. Am. Ind. Hyg. Assoc. J 25:439-46.

Erley, D.S., J.J. Gay, C.L. Hake, A.W. Schaffer and R.D. Stewart. 1961. Human exposure to $1,1,1$ - Trichloroethane vapor-relationship of expired air and blood concentrations to exposure and toxicity. An. Ind. Hyg. Assoc. J 22: 252-62.

Feiner, B. and $M$. Kleinfeld. 1966. Health hazards associated with work in confined spaces. J. Occup. Med. $8: 358-64$.

Frawley, P.J. 1964. 1,1,1 - Trichloroethane--Emergency exposure limits, in emergency exposure limits. Am. Ind. Hyg. Assoc. Toxicology committee. Am. Ind. Hyg. Assoc. J 25: 585-86.

Fullerson, J.E., N. Hicks, J.R. Imbus, C.G. Kramer and G.M. Ott. 1976. Health of workers exposed to $1,1,1$

-Trichloroethane--a matched pair study. Dow Chemical Co., Midland, Mich. 20 pp.

Fulkerson,m J., D. Ritzema and L. Skory. 1974. Vapor degreasing solvents--when safe? Product Finishing $\mathrm{Co}$., Los Angeles, California 8-9 pp.

Guy, C.U. and E. J. Otterson. 1964. A method of atmospheric solvent vapor sampling on activated charcoal in connection with gas chromatography. Pages $37-43$ in Transaction of the 26 th annual meeting, American conference of governmental industrial hygienists, Philadelphia, Pa.

Hoyle, H.R., J.E. Peterson and E. J. Schneider. 1956. The analysis of air for halogenated hydrocarbon contaminants. Am. Ind. Hyg. Assoc. J 17:429-33.

Kay, R.W. 1973. Survey of toxic hazards during vapor degreasinng with Trichloroethylene and 1,1,1 - Trichloroethane. Ann. occup. hyg. 16: 417-19.

Kupel, R.E., P.A. Mauer, D.G. Taylor and L.D. White. 1970. a convenient optimized method for the analysis of selected solvent vapors in the industrial atmosphere. Am. Ind. Hyg. Assoc. J 31:225-32. 
McCollister, D.D., F. Oyen, V.K. Row and T. R. Torkelson. 1958. Toxicity of $1,1,1$ - Trichloroethane as determined on laboratory animals and human subjects. Am. Ind. Hyg. Assoc. J 19:353-62.

Moss, I.M. and J. H. Simmons. 1973. Measurement of personal exposure to $1,1,1$ - Trichloroethane using an inexpensive samplig device and battery-operated pump. Ann. Occup. Hyg. 16:47-49.

Nelson, G.O. and E. G. Shapiro. 1971. A field instrument for detecting airborne halogen compound. Am. Ind. Hyg. Assoc. J 32:757-65.

OSHA. 1976. National Institute for OSHA U.S. Dept. Of Health, Education and Welfare, Public Health Service Center for Disease Conrol. 1976. Criteria for a recommended standard occupational exposure to 1,1,1 - Trichloroethane. $36-37 \mathrm{pp}$.

Row, V.K., S.E. Sadek, R.D. Stewart, M.A. Wolf and T. Wujkowski. 1963. Toxicity of a solvent mixture of 1,1,1 - Trichloroethane and Tetrachloroethylene as determined by experiments on laboratory animals and human subjects. Am. Ind. Hyg. Assoc. J 24: 541-42.

Stewart, R.D. 1963, The toxicology of methyl chloroform. J. Occup. Med. 6:259-60.

Stewart, R.D. 1968. The toxicology of 1,1,1 - Trichloroethane. Ann. Occup. Hyg. 11:71-72.

Stewart, R.D. 1971. Methyl chloroform intoxication-diagnosis and treatment. JAMA 215: 1789-92. 


\section{APPENDIX}

\section{PHYSICAL PROPERTIES OF $1,1,1$ - TRICHLOROETHANE}

Molecular Formula

Appearance

Formula weight

Melting Point

Boiling Point

Vapor Density

Specific Gravity

Solubility

Density of Saturated Air

Concentration of Saturated Air 16.78 by volume at

Flammable (explosive limits)

Flash Point

Autoignition Temperature

Vapor Pressure

Freezing Point $25 \mathrm{C}$

$\mathrm{CH} 3 \mathrm{CCL} 33$

Clear, free from suspended matter

133,41

-32.63 C $(-26.7$ F. $)$

$74.0 \mathrm{C}(165.2 \mathrm{~F}) \quad 760 \mathrm{~mm}$ $\mathrm{Hg}$

$4.6($ air $=1)$

$1,339(20 \mathrm{C})$ (water -1.000 at 4 C)

$0.44 \mathrm{~g} / 100 \mathrm{~g}$ water at $25 \mathrm{C}$; soluble in ethyl ether, ethyl alcohol

$1.6($ air $=1)$

10-158 in air with hot wire ignition

None

$500 \mathrm{C}(932 \mathrm{~F})$

Temp. F Temp. C $\mathrm{mm} \mathrm{Hg}$

$\begin{array}{rrr}50 & 10 & 62 \\ 68 & 20 & 100 \\ 77 & 25 & 127 \\ 86 & 30 & 150 \\ 104 & 40 & 240\end{array}$

$37.9^{\circ} \mathrm{C}$ 
Heat of Vaporation

at Boiling Point

$54.4 \mathrm{cal} / \mathrm{gm} ; 98 \mathrm{BTU} / \mathrm{lb}$.

Specific Heat, Liquid at

$20 \mathrm{C} \mathrm{Cal} / \mathrm{gm} / \mathrm{O}_{\mathrm{C}} \quad 9.25$

Critical Temperature

$272.5^{\circ} \mathrm{C}$

Thermal Conductivity, 2 iquid

at $20^{\circ} \mathrm{C}, \mathrm{BTU}: \mathrm{hr} / \mathrm{ft} \mathrm{L}^{2}$,

$\begin{array}{ll}\mathrm{o}_{\mathrm{F} / \mathrm{ft}} & 0.080\end{array}$

Pounds per gallon at $25^{\circ} \mathrm{C}$

10.97

Average Coefficient of

Cubigal Expansion, Liquid

per $\mathrm{C}$, 0 to $40^{\circ} \mathrm{C}$

0.00116

Specific Gravity of Vapor at 1

ATM \& b. pt. (air = 1) 4.6

Viscosity, Liquid at $20^{\circ} \mathrm{C}$; centipoise

0.86

Dielectric strength, Liquid at $25^{\circ} \mathrm{C}$

$25 \mathrm{KV}$

Explosion Point

None

Evaporation Rate (ether - 100) 35

Conversion Factors

(25 C $760 \mathrm{mmHg}$ )

$1 \mathrm{mg} / \mathrm{liter}-\mathrm{lg} / \mathrm{cu}$

$\mathrm{m}=\mathrm{ppm}$

$1 \mathrm{ppm}=5.46 \mathrm{mg} / \mathrm{cu} \mathrm{m}$

$=5.46 \mathrm{ug} / \mathrm{liter}$

Loss Ratio of Degreaser Solvent $0.142 \mathrm{lb} / \mathrm{hr} / \mathrm{sg}$. ft.

Distillation Range, $760 \mathrm{~mm} \mathrm{Hg} 72-88^{\circ} \mathrm{C}$

Free Halogens

None

Acidity, as HCI, wt. \&

$0.001 \max$.

Non-volatile, Matter, wt. 8

$0.0001 \max$.

water, wt. \&

$0.0100 \max$.

Purity:

$1,1,1-T r$ ichloroethane content, wt. 8

$96.0 \mathrm{~min}$. 
1,1,1-trichloroethane content vol. \& Individual Halogenated Impurities, wto Total Halogenated

Impurities, wt. 8 $95.0 \mathrm{~min}$. $0.5 \max$.

$1.0 \max$.

Acid Acceptance as NaOH, Wt. \& $0.20 \mathrm{~min}$. 
STANDARDS FOR CHLORINATED SOLVENTS

$$
\begin{aligned}
& \text { Material Time-Weighted Threshold Limit } \\
& \text { Average-ANSH Values-ACGIH }
\end{aligned}
$$

solvent 111

$\underline{P P M}$

$\underline{P P M}$

(1,1,1-trichloroethane) 400 350*

Trichloroethylene 100* 100

Perchloroethylene 100* 100

Methylene Chloride 500* 200 (pending)

*Values adopted by OSHA regulations (29CFR Part 1910 Subpart G)

PERMISSIBLE LEVELS OF

$1,1,1-T R I C H L O R O E T H A N E$ IN

THE WORKING ENVIRONMENT OF FIVE COUNTRIES

\section{Country}

Finland

Germany (Fed. Rep.)

Japan

Yugos lavia

Rumania

$$
\frac{\text { Standard }}{\mathrm{mg} / \mathrm{cu} \mathrm{m} \mathrm{ppm}}
$$

Qualifications

$2,700 \quad 500$

$1,080 \quad 200$

MAC

$1,900 \quad 350$

None stated

$1,080 \quad 200$

None stated

$1,000 \quad 185$

None stated 